\title{
The Effect of Corporate Governance in Palestine on the Efficiency of Internal Audit: Empirical Evidence
}

\author{
Suhaib Tawfiq Jarrar ${ }^{1}$ \\ ${ }^{1}$ Accounting Department, Arab American University- Jenin, Jenin, Palestine (West Bank) \\ Correspondence: Suhaib Tawfiq Jarrar, Accounting Department, Faculty of Administrative and Financial \\ Sciences, Arab American University- Jenin, Jenin, Palesine (West Bank), P.O. BOX 240, Jenin -West Bank, \\ Palestine. Tel: 970-59909-0615. E-mail: Suhaib.jarrar@aauj.edu
}

Received: February 20, 2016

Accepted: March 9, 2016

Online Published: April 25, 2016

doi:10.5539/ijef.v8n5p124

URL: http://dx.doi.org/10.5539/ijef.v8n5p124

\begin{abstract}
This paper comes to examine the impact of corporate governance in Palestine on the efficiency of internal audit from the reality of the listed corporations in the Palestine Exchange; [PEX]. The population of this paper consists of all the 25 listed Palestinian companies in the Palestine Exchange that have internal auditor. It also includes another 5 companies that rely on the internal audit by external companies. Hence, the number of the reviewed companies by this study is 30 companies (Palestine Exchange Market). Thereupon, 30 questionaires were distributed and retrived. However, this manuscript states a summary of the most important results. These results are explained as is shown in the following: (1) the findings of the study state that there is an effect of applying the variables of corporate governance altogether on the quality of the internal audit of the listed public companies in the Palestine Exchange. These rules are (disclosure and transparency, accountability, responsibility, justice, and independency). (2) The results of the study indicate that there is a significant effect of applying the corporate governance variables individually on the quality of the internal audit of the listed public companies in the Palestine Exchange. Thus, the effect of these variables appears contrasted respectively as the following: disclosure and transparency, justice and accountability, independency and responsibility. (3) The corporate governance represents combining the right practices and procedures which operate within the standards and rules that governed by the obligatory standards. These standards aim at ensuring that there aren't any contradictions between the strategic goals of the company and the fuctional procedures of the administration in achieving these goals. (4) The internal audit adds value to the company through the functions that enhance its performance within corporate governance. This includes providing information to all levels of the management, evaluating the system of the internal control and the risk management, in addition to sticking the company with the principles of corporate governance. The findings of the study come up with the following recommendations: (1) the study assures the importance of applying the corporate governance principles because of their clear effect on the internal audit quality. It also recommends working efficiently on the professional development of the auditors and improving their performance through training programs, as well, encouraging them to keep up with the latest developments in the field of the auditing and other related fields. (2) It strongly recommends working on enhancing and activating the role of the board of directors and the audit committee; as well as granting them the independency. Hence, they will be able to carry out the tasks assigned to them. Consequently, they will avoid the effects that the company may be exposed to as a result of the internal weakness of the practical aspects of the principles of corporate governance; in addition to the negative impacts of this issue on the quality of the internal audit.
\end{abstract}

Keywords: internal audit, corporate govenance, Palestine Exchange, conflict of interest, disclosure, transparency, accountability, responsibility, justice, independency

\section{Introduction}

The economic and financial realities in Palestine have witnessed lots of development lately; as well as the appearance of several modern strategies and concepts in the Palestinian economic system subsequently to the establishment of public companies. The appearance of these companies and new development in economy altogether brought various economic concepts which the Palestinian companies haven't been used before this new era. Thus, the most eminent concept appears to be the internal audit and corporate governance; in addition to 
establishing their own committees.

The internal audit turned out to be an important management for public companies. Thus, the standing of the internal audit takes increasingly further importance when the company gets bigger and when the number of users of financial statements is increased. Hence, the task of auditing will become more difficult because of the fact that this data is the base on which the users depend on for decision-making.

Globalization and the rapid development in modern means of communication led to create a new atmosphere for competition on the local and external levels of the operating companies in Palestine. In recent years, the Palestinian Authority issued a number of legislations to organize the private sector including corporate governance rules due to its importance for the Palestinian economy. Thus, "They established the National Committee for Corporate Governance in Palestine. The Committee decided to create a technical team to work on drafting the code of corporate governance depending on the principles and an action plan developed by this committee. The technical team aims at preparing the rules of corporate governance in Palestine in accordance with the conditions and legislation in Palestine, taking into account the international principles and standards regarding corporate governance at the regional and international levels (Code of Corporate Governance for Palestinian companies).

The eminent role of both internal audit and corporate governance in economy increases the importance of this study which tries to find relationship between these two terms; especially the effect of rules for applying the governance in the company on the quality of internal audit. Hence, this study is one of the few studies in Palestine that aims at finding a relationship using basic measurements so as to value the effectiveness of the internal audit under the governance of the Palestinian companies.

However, this study contains a questionnaire so as to achieve its goals. The questionnaire distributed among the listed public companies in the Palestine Stock Exchange which has a committee of internal audit.

There is no doubt that the separation of ownership from the management of public companies and the permanent pursuit of the company's administration to achieve personal interests by drawing the company's strategies or by using innovative accounting system; would lead to a direct impact on the overall situation of the company's interests. This also would affect the granted confidence to the managers by the board of directors. Hence, it comes to be a necessity to create the internal audit department, which provides the board of directors with the general situations of the company. Therefore, there are many variables that affect the achievement of operating the internal audit efficiently and in the right and desired way. However, the most important variable that needs to be studied carefully is applying the rules of corporate governance. Hence, the problem of this study explores the following key question: What is the effect of corporate governance in Palestine on the efficiency of the internal audit?

\section{Previous Studies}

The previous studies have an important role to establish a conceptual framework and a fundamental base to clarify the basic aspects of this study. Unfortunately, a few and insufficient studies were found about the Palestinian economy reality. Hence, the study referred to Arabic studies related to the subject of governance and its impact on the internal audit. The following is a review of some of these studies.

The paper of (Tabara \& Ungureanu, 2012) shows that the corporate governance implies a cycle that extends from the steering and monitoring role of the board, to the administrative and operational executives and the role of internal and external auditors certification. These roles come from three different levels of governance. Efficiency level can impact another, but also governance throughout the organization. In this sense, the system includes all activities, from monitoring, operation and control to the processes and activities to meet the needs of different stakeholders. Implementing a system of corporate governance involves the basic principles leading to relations between different participants, to define responsibilities and ensure the correct operation of the decision making process. A well, based information system is essential for optimal functioning of organizations, but also for their future development.

The paper of (Al-Jabali, Abdalmanam, \& Ziadat, 2011) shows that the regulatory controls are in force in any company has been developed to face the major risk of the institution. The management of the company or organization applies supervisory controls. While other participants in the governance (And here is the Internal Auditor) Playing a more role in Supervisory control or evaluation, Where can the Internal Auditor providing assurances about the supervisory controls, and that in terms of assessment of the procedural methods in senior management.

The paper of (Karagiorgos et al., 2010) shows that within the globalized economy, internal auditing is 
established as an essential means for the exact management of any business economic resources. Simultaneously, corporate governance has received wide attention in recent years both in practice because of the major accounting scandals and large-scale corporate failures. In this concept, the main purpose of the present paper is to examine in a theoretical level the contribution of internal auditing to corporate governance. Furthermore this paper aims to examine the interaction between various corporate governance factors, such as the board of directors, the audit committee and the external auditor, and the internal audit process. Via an extended literature review, the study's originality is the provision of an integrated conceptual framework regarding internal audit and business corporate governance. The results of this literature review indicate that internal auditing plays a vital role in effective corporate governance.

Moreover, the study of (Zuelf \& Jawhar, 2007) explores the relationship between the internal control elements and the corporate governance. As well as, it clarifies the level to which have these elements contributed in enhancing the basics of internal control and corporate governance. The study shows a set of results emphasizing that the success of corporate governance requires adopting the internal control elements by the financial organizations. Hence, all of these elements have an important role in enhancing the corporate governance.

Furthermore, the study of (Joshua, 2006) provides a proposal aims at improving the company governance through the insurance of the financial statement risks as well as eliminating the conflict of interest. However, the conflict of interest is a permanent source of threat to the relationship between the internal auditor and the clients, which also affects the quality of financial statements.

Therefore, the study of (Mangena \& Pike, 2005) aims at exploring the relationship between corporate governance and the level of disclosure. This study figured out this relationship through studying the impact of some of the company's shareholders and the size of audit committee in addition to the experience in financial issues on its performance. Hence, the study concludes a set of results. The most important result states that there is a statistical relationship amongst the level of disclosure, the characteristic of the shareholders, the size of audit committee as well as the experience in financial affairs.

The study of (Rezaei, 2003), explores the business of American firms so as to identify the role of audit committees in improving the joint ruling of the organization. Thus, this study suggests some guiding principles for institutional governance. However, the most important pointer of these guiding principles is choosing the company's Chief Executive Officer (CEO) by the board of directors. Also, it must be taken in account that the management of the company must control operational activities and preparing the financial statements of the company effectively and in ethical way to raise the gained shareholder value.

Similarly, the study of (Juma, 2003) explores the corporate governance issue and the dimensions of development in using the internal audit. It also explains the impact of development in using the internal audit to support the corporate governance in the Jordanian companies within the local legislations.

\section{Theoretical Framework}

\subsection{Corporate Governance and Internal Audit}

However, various literatures show that corporate governance can achieve its objectives by relying on the basics of internal control. The basics of internal control are explained as in the following:

1)- Disclosure and transparency: transparency means providing data in order to protect the shareholders' future and to make the community recognizes that the organization is able to fulfill its obligations. Thus, Transparency is an important element to ensure justice, fairness and confidence when applying the procedures taken by the management of the organization and its personnel, (Khoury, 2003, p. 3). As well as, the importance of transparency arose after the growing of the economic role of the financial markets, and when the financial statements become an important source of information for decision-making (Mat'ar, 2003, p. 5). However, the information that is revealed with financial reports is provided in the form of notes or attached tables or within the financial statements. As well as, this information is a fundamental part of these financial statements. Hence, the disclosed data must be revealed in honest and fair way and with objectivity amongst all shareholders and stakeholders in time and without delay.

2)- Accountability: it means the responsibility of the organization to perform a continuous reviewing and evaluation of the management by the relevant parties such as stakeholders, personnel, in addition to the community. This could be applied by providing the organization internally with controlling structure representatives including committees of independent audit as well as the internal controlling to carry out its duties independently.

However, (Hermanson \& Rittenberg) explained that the achievement of the organization targets require the 
following parties to undergo questioning before the stakeholders. These parties are the board of directors, the audit committee, senior management, internal audit and external audit (Hermanson \& Rittenberg, 2003, p. 30).

3- Responsibility: it means that the company must have a moral message to be carried out in the community and that managers recognize that they have a duty toward the working staff, improving the services provided to them, and to protect the environment, too.(Carroll, 2003, p. 4). Hence, (Credit Lyonnais SA) Bank explains responsibility in the following paragraphs (Gill, 2003, p. 66): Responsibility is the existence of the efficiency and effectiveness of the board of directors, developing punishment procedures that allow punishing executives and board of director members, in addition to act effectively against individuals who exceed their limits. Also, there should be transparency and fairness in dealing with stocks by the members of the board of directors.

4- Justice: it means to respect the rights of the stakeholders in the company, and distributing the tasks, duties and responsibilities among employees on the basis of justice and equality (the Saudi Organization for Certified Auditors, 2007, p. 14). Hence, the Organization for Economic Cooperation and Development (OECD) assured the need to develop systems aiming at preventing workers of the organization including managers from taking advantage of their positions. As well, the members of the board of director must declare any personal interests in the organization's operations.

5- Independency: Independency aims at reducing or eliminating conflicts of interest by creating independent committees, appointing auditors and preventing any domination of any party or side to control or affect the decisions of the board of directors (Khoury, 2003, p. 3). Also, the internal audit standards issued by the Institute of Internal Auditors in the United States emphasized on the importance of the independency and objectivity of the internal auditor in performing the duties especially when these duties relate to the highest position in the organization. Moreover, it stressed that the auditor must have integrity without any bias or conflict of interest (Jane, 2003, p. 242).

Hence, the internal audit role should not be limited to the financial field, but it must be comprehensive to all aspects of the organization (Abdullah, 2000, p. 181) states that the internal audit is "a set of systems or different independent activities of the project that is established by the administration. It firstly aims at recognizing the transactions and entries in a continuous way in order to ensure the accuracy of both the accounting and statistical data. The second purpose comes to ensure the adequacy of the value of reserves to protect the assets and property of the project; as well as ensuring that the project staff follow the policies and administrative plans and drawn procedures. Also, it measures the validity of those plans, policies and all other means of control in the performance; in addition to suggesting improvements until the project reaches the point of maximum production efficiency".

Regarding professional organizations, the Arab Society of Certified Accountants (ASCA, 2001, p. 227) defines the internal audit as "an internal function of the department established to reflex the activity of internal independently in order to establish administrative control, including accounting control evaluate matching system with the requirements of the department or to work on the proper use of resources in order to achieve maximum production efficiency.

\subsection{Quality of Internal Audit}

Quality is defined briefly as the level of matching the requirements of the organization where the organization seeks to monitor the performance and the activities; in addition to measure its daily transactions to reach the highest degree of quality. This would be achieved by reducing errors and detecting variances report which leads to meet the needs of the management. The internal audit quality depends on the quality of performance of the internal control system and the appropriateness of the applied accounting system that aims to reach the efficiency and proper effectiveness in the transactions and entries. This performance must be continuous to achieve the objectives of the organization in order to serve and protect the assets (Al-Qadi, 2008, p. 103).

Professionally, audit quality is defined as the ability of the audit to identify the weaknesses in the internal control system, and make recommendations to get rid of these faults or reduce them. Thus, the possibility of achieving the maximum benefit to the organization will be increased. Academically, audit identified as a commitment to both auditing standards and rules of ethical behavior when doing the task of auditing (Dirdis, 2010, p. 40).

The standards of internal and external audit categorize the vital factors to determine and ensure the internal audit quality. Hence, the American Institute of Certified Public Accountants (AICPA, 1991) states the list of auditing standards No. 65 indicates that the quality of the internal audit includes the qualification factors that measured through the academic qualification and professional certificates and objectivity. Thus, these standards are measured by the internal audit reports and the board responsible for the appointment or dismissal of internal 
auditors. The quality of the transactions performance is measured by the accuracy and adequacy of audit programs and the scope of the auditing. In contrast, the Institute of Internal Auditors standards explain the quality factors of the internal auditing with independency, objectivity, professionalism, and proper care (IIA, 2003).

\section{Hypotheses}

This study focuses on a specific theme titled 'the effect of corporate governance in Palestine on the efficiency of internal audit'. This theme deals with one major hypothesis with two major variables. The first variable is static, represents applying the rules of governance. The second variable is dependent, represents the effectiveness and efficiency of internal audit. Hence, the first hypothesis question is: Is there an effect of applying the rules of corporate governance on the effectiveness of the internal audit? If the answer is yes; what is the level of this effect?

However, this hypothesis results the following sub-hypotheses:

I. The first sub-hypothesis states that applying the disclosure and transparency haven't significant statistical effect on the quality of internal auditing of the listed public Palestinian companies in the Palestine Exchange.

II. The second sub-hypothesis explains that there is no significant statistical effect of applying accountability on the quality of internal auditing of the listed public companies in the Palestine Exchange Market.

III. The third sub-hypothesis clarifies that there is no significant statistical effect of applying responsibility on the quality of internal auditing of the listed public companies in the Palestine Exchange Market.

IV. The fourth sub-hypothesis states that there is no significant statistical effect of applying justice on the quality of internal auditing of the listed public companies in the Palestine Exchange Market.

V. The fifth sub-hypothesis clears up that there is no significant statistical effect of applying independence on the quality of internal auditing of the listed public companies in the Palestine Exchange Market.

\section{Methodology}

This section of the paper presents the methodology as following:

\subsection{Data}

The methodology of this study relies on examining the companies that have corporate governance rules and own a specialized internal audit department and internal auditor. It also relies on the companies that depend on the internal auditing by external companies. Furthermore, it prepares questionnaires and distributed them to these companies. Then, it analyses the given data of the distributed questionnaires by using the statistical package for the social sciences (SPSS) to identify these results and then coming up with the recommendations.

\subsection{Population and Sample}

The population of this paper consists of all the 25 listed Palestinian companies in the Palestine Exchange that have internal auditor. It also includes another 5 companies that rely on the internal audit by external companies. Hence, the number of the reviewed companies by this study is 30 companies (Palestine Exchange Market).

\subsection{Paper Tool}

This study employs a questionnaire as the variables of the study required; where this questionnaire consists of two parts. The first part aims at recognizing the demographic factors of the members of the study sample. In contrast, the second part focuses on the statements of the study variables that measure the effect of applying corporate governance on the quality of the internal audit. These variables are explained as disclosure and transparency variable, accountability variable, responsibility variable, justice variable, independency variable, in addition to the internal audit quality variable.

\section{Descriptive Statistic}

Table 1 explains that the highest percentage of scientific specialization that rates $50 \%$ is in accounting. The finance comes secondly; rating $27 \%$.Business administration comes thirdly, rates $23 \%$. These findings state that the population of the study sample are qualified to work in the accounting and financial field.

Table 1 also illustrates that $73 \%$ of the population hold bachelor degree; whereas the percentage of those who obtain a master's degree is $17 \%$. In contrast, the $\mathrm{PhD}$ holders take $10 \%$. Hence, we notice that the level of educational degree of the study population is high. That's because the education in Palestine is considered as an 
important element in life.

Table 1 also shows that the percentage of accountants is $43 \%$, whereas, the internal audit managers and the internal auditors come with $40 \%$ of the study sample. In contrast, the chief of accounting departments come with $17 \%$ )of the study sample which is the lowest one. However, the percentage of accountants is $43 \%$ which is the highest percentage of the study sample over the rest of the other majors.

Therefore, Table 1 states that the percentage of the study sample are experts in their fields by 5 years or less, rating $26 \%$. Also, the percentage of the study sample are experts in their fields $6-10$ years rates $7 \%$ of the study sample. The category 11-15 years rates 30\%. Also, the category 16-20 years rates 13\%. The 21 years and more represent $27 \%$. This indicates that the experience of the study sample population is sufficient enough to do their tasks. It gives them additional positive specifications which qualify them to deal with the accounting matters professionally. Also, the aforementioned features show the ability of the study sample to understand the questionnaire questions and answer them.

Table 1. The Distribution of the study sample according to the demographic specifications

\begin{tabular}{|c|c|c|c|}
\hline Variable & Explanations & Frequencies & $\%$ \\
\hline & Accounting & 15 & 50 \\
\hline \multirow[t]{2}{*}{ Specialization } & Finance & 8 & 27 \\
\hline & Public Administration & 7 & 23 \\
\hline \multirow[t]{4}{*}{ Academic qualifications } & Bachelor & 22 & 73 \\
\hline & Master & 5 & 17 \\
\hline & Ph.D. & 3 & 10 \\
\hline & Manager or internal audit & 12 & 40 \\
\hline \multirow[t]{4}{*}{ Position } & Head of accounting department & 5 & 17 \\
\hline & accountant & 13 & 43 \\
\hline & 5 years and less & 8 & 26 \\
\hline & $6-10$ years & 2 & 7 \\
\hline \multirow[t]{3}{*}{ Experience period } & 11-15years & 9 & 30 \\
\hline & $16-20$ years & 4 & 13 \\
\hline & More than 21 years & 7 & 27 \\
\hline
\end{tabular}

\section{The Results}

Presented below are the results of this paper that classified according to the variables of this paper:-

\subsection{Disclosure and Transparency Variable}

Table 2. Arithmetic means and standard deviations of the disclosure and transparency variable

\begin{tabular}{|c|c|c|c|}
\hline Item & Average & Standard Deviation & Sig. \\
\hline $\begin{array}{l}\text { The disclosure of important information proceeds in a fair, } \\
\text { unbiased and honest manner. }\end{array}$ & 4.15 & 0.712 & High \\
\hline $\begin{array}{l}\text { The disclosure of important information is objective, honest } \\
\text { and straight. }\end{array}$ & 4.125 & 0.852 & High \\
\hline $\begin{array}{l}\text { The disclosure of important information meets the deadline } \\
\text { and without delay. }\end{array}$ & 3.985 & 1.056 & High \\
\hline $\begin{array}{l}\text { Information is provided regarding the largest ownership of } \\
\text { the shares in the company. }\end{array}$ & 3.785 & 1.452 & Medium \\
\hline $\begin{array}{l}\text { Providing information regarding the members of the board } \\
\text { of directors. }\end{array}$ & 3.425 & 1.236 & Medium \\
\hline Providing information with respect to the chief executives. & 3.521 & 1.158 & Medium \\
\hline Mean & 3.831 & 0.953 & High \\
\hline
\end{tabular}

Table 2 states that the significant level of the disclosure and transparency variable ranged between high to medium; where their arithmetic averages rate 3.425 - 4.15. The general result shows a high level of the impact of disclosure and transparency in the quality of internal audit of the listed Public companies in the Palestine 
Exchange. Hence, the arithmetic average of the study sample answers rates 3.831. The standard deviation rates 0.953. The aforementioned low value indicates that the answers of the study sample are nearly close and similar. As well, this result matches the findings of the study of (Fateh \& Ai'she, 2008) which shows the importance of corporate governance as monitoring framework to ensure the honesty and integrity of the revealed financial data.

\subsection{Accountability Variable}

Table 3 shows that all of the levels of the accountability variable are significantly high in term of influence; wherein the deviation averages rate 3.785-4.128. Hence, the general result of the study sample states that there is a high level of influence of accountability on the quality of internal audit of the listed public companies in the Palestine Exchange. The arithmetic average of the answers reaches 3.912. In contrast, the standard deviation reaches 0.927 which shows resemblance between the answers to some extent.

Table 3. Arithmetic means and standard deviations of the accountability variable

\begin{tabular}{|c|c|c|c|}
\hline Item & Average & Standard Deviation & Sig. \\
\hline $\begin{array}{l}\text { An assessment and evolution are made regarding the performance } \\
\text { of the executive management. }\end{array}$ & 3.785 & 0.816 & High \\
\hline $\begin{array}{l}\text { The tasks that ensure doing the transactions accurately by the rest } \\
\text { of the company's staff are implemented. }\end{array}$ & 4.128 & 0.922 & High \\
\hline Periodic reports of the results of the transactions are provided. & 3.924 & 1.089 & High \\
\hline The level of success in applying the periodic reports is evaluated & 3.812 & 0.910 & High \\
\hline Mean & 3.912 & 0.927 & High \\
\hline
\end{tabular}

\subsection{Responsibility Variable}

Table 4 indicates that the significant levels of the responsibility variable rate between high and medium with deviation average between 3.562-4.012. Hence, the general result of the study sample states that there is a high level of influence of the responsibility variable on the quality of internal audit in the listed public companies in the Palestine Exchange. Furthermore, the arithmetic average of the answers reaches 3.861. In contrast, the standard deviation reaches 0.981 which shows resemblance of the answers to some extent.

Table 4. Arithmetic means and standard deviations of the responsibility variable

\begin{tabular}{|c|c|c|c|}
\hline Item & Average & Standard Deviation & Sig. \\
\hline $\begin{array}{l}\text { There is emphasis and assurance on the ethical message of the company in the } \\
\text { community. }\end{array}$ & 3.925 & 0.912 & High \\
\hline Managers are committed to their responsibilities towards the community. & 4.012 & 0.825 & High \\
\hline There is a commitment with the responsibility for protecting the environment. & 3.562 & 1.035 & Medium \\
\hline $\begin{array}{l}\text { There is a commitment with the obligations toward the employees in improving } \\
\text { the services provided to them. }\end{array}$ & 3.921 & 0.815 & High \\
\hline $\begin{array}{l}\text { There is a commitment with the responsibilities toward the shareholders in } \\
\text { achieving the appropriate returns. }\end{array}$ & 3.892 & 1.082 & High \\
\hline Mean & 3.861 & 0.981 & High \\
\hline
\end{tabular}

\subsection{Justice Variable}

Table 5 explains that all of the significant levels of justice variable achieve the highest level of influence where these levels rate 3.785-4.054. Hence, the general conclusion of the study sample shows a high significant level of influence for the justice variable on the quality of internal audit in the listed public companies in the Palestine Exchange. Therefore, the arithmetic average reaches 3.891; while the standard deviation reaches 0.915.This low value indicates that the answers of the study sample are convergent to some extent. Hence, this result is consistent with (Rezaee, 2003) study, which is one of the guiding principles about the management responsibility for preparing financial statements under the supervision of the board of directors and the audit Committee. Its purpose aims at exposing the financial position of the company fairly and at a certain date; in addition to show the results of its transactions in a specified period of time. 
Table 5. Arithmetic means and standard deviations of the justice variable

\begin{tabular}{lccc}
\hline Item & Average & Standard Deviation & Sig. \\
\hline The rights of all stakeholders in the company are respected. & 3.921 & 0.801 & High \\
The distribution of the tasks and duties among the company' employees are & 4.054 & 0.920 & High \\
distributed on the basis of justice and equality. & & & \\
The shareholders are treated on the basis of justice and equality. & 3.785 & 1.0352 & High \\
The revenue of the company is distributed on the basis of justice and equality. & 3.812 & 1.052 & High \\
Mean & 3.891 & 0.915 & High \\
\hline
\end{tabular}

\subsection{Independency Variable}

Table 6 shows that all of the significant levels of the independency variable reach the medium level of influence. Hence, the general conclusion of the study sample shows a medium significant level of influence for the independency variable on the quality of internal audit in the listed public companies in the Palestine Exchange; wherein these levels rate between 2.620 - 3.621. As well, the arithmetic average reaches 3.354; while the standard deviation reaches 1.19. This result is consistent with the findings of (Isa, 2008) study, which identifies that increasing the objectivity of internal auditors by expanding the level of independency leads to improve the quality of the internal auditing.

Table 6. Arithmetic means and standard deviations of the independency variable

\begin{tabular}{lccc}
\hline Item & Average & Standard Deviation & Sig. \\
\hline $\begin{array}{l}\text { The auditor is not exposed to any effects while doing the tasks. } \\
\text { The auditor accomplishes the work with objectivity and integrity and without } \\
\text { any bias or conflict of interests. }\end{array}$ & 3.521 & 1.25 & $\begin{array}{c}\text { Medium } \\
\text { Medium }\end{array}$ \\
$\begin{array}{l}\text { The employees of the company have an intellectual independence in relation } \\
\text { to all of the works assigned to them. }\end{array}$ & 3.412 & 1.13 & Medium \\
$\begin{array}{l}\text { The employees avoid any relationship that may lead to lose their objectivity } \\
\text { and expose them to the dominance of other parties. }\end{array}$ & 3.598 & 1.25 & Medium \\
$\begin{array}{l}\text { There is a relationship between lacking of objectivity and independency when } \\
\text { doing the assigned tasks. }\end{array}$ & 2.620 & 3.18 & Medium \\
Mean & & 3.19 & Medium \\
\hline
\end{tabular}

\subsection{Internal Auditing Quality Variable}

Table 7. The arithmetic means and standard deviations of the internal audit quality variable

\begin{tabular}{|c|c|c|c|}
\hline Item & Average & Standard Deviation & Sig. \\
\hline The level of education contributes in improving the quality of the auditor' performance. & 4.26 & 0.44 & High \\
\hline $\begin{array}{l}\text { Having a professional certificate contributes in improving the quality of the internal auditor } \\
\text { performance. }\end{array}$ & 4.48 & 0.50 & High \\
\hline $\begin{array}{l}\text { Continuing education contributes in improving the quality of the professional performance of the } \\
\text { auditor. }\end{array}$ & 4.60 & 0.49 & High \\
\hline $\begin{array}{l}\text { The professional experience of the internal audit contributes in improving the quality and the } \\
\text { performance of the internal auditor. }\end{array}$ & 4.22 & 0.68 & High \\
\hline $\begin{array}{l}\text { Previous knowledge regarding the transactions and the work procedures of the company contribute in } \\
\text { improving the quality of the performance of the internal auditor. }\end{array}$ & 4.36 & 0.48 & High \\
\hline The technical training contributes in improving the level of performance of the internal auditor. & 4.62 & 0.48 & High \\
\hline Average of the eligibility index & 4.42 & 0.51 & High \\
\hline $\begin{array}{l}\text { Providing the internal audit report for the senior management and the audit committee contributes in } \\
\text { improving the quality of the internal audit. }\end{array}$ & 3.85 & 0.59 & High \\
\hline $\begin{array}{l}\text { The appointment, promotion, upgrading and the dismissal of the internal auditors by the senior } \\
\text { management and the audit committee contribute in improving the performance quality of the internal } \\
\text { audit. }\end{array}$ & 3.75 & 0.65 & High \\
\hline $\begin{array}{l}\text { The external auditors contribute in improving the internal audit functions quality and the performance } \\
\text { of the internal audit function. }\end{array}$ & 4.13 & 0.60 & High \\
\hline The internal auditor ties with the senior management contribute in improving the performance quality. & 4.39 & 0.49 & High \\
\hline
\end{tabular}




\begin{tabular}{|c|c|c|c|}
\hline The average of objectivity variable & 4.03 & 0.58 & High \\
\hline $\begin{array}{l}\text { The accuracy and efficiency of the internal audit programs enable improving the quality and } \\
\text { performance of the internal audit. }\end{array}$ & 4.00 & 0.52 & High \\
\hline $\begin{array}{l}\text { The internal auditor professional care contributes in improving the quality and performance of the } \\
\text { internal audit. }\end{array}$ & 3.97 & 0.50 & High \\
\hline $\begin{array}{l}\text { The senior management support for the internal audit function contributes in improving the internal } \\
\text { audit performance. }\end{array}$ & 4.11 & 0.31 & High \\
\hline $\begin{array}{l}\text { The assessment of the performance quality by external parties contributes in raising the performance } \\
\text { level of the internal audit. }\end{array}$ & 4.11 & 0.32 & High \\
\hline $\begin{array}{l}\text { The adequacy and the scope extent of the internal audit function lead to achieve the quality and } \\
\text { performance of the internal audit. }\end{array}$ & 3.45 & 0.73 & $\begin{array}{c}\text { Medi } \\
\text { um }\end{array}$ \\
\hline Average of the performance quality index & 3.92 & 0.38 & High \\
\hline The internal audit quality variable average & 4.15 & 0.49 & High \\
\hline
\end{tabular}

Table 7 explains the three groups of the internal audit quality variable. Hence, the first group has six paragraphs that deal with the appropriateness index. Whereas, the second group, which includes four paragraphs is related to the objectivity index. In contrast, the third group relates to the performance quality and includes the last five paragraphs. Herein, Table 7 states the following explanation:

A. The arithmetic mean of the eligibility index rates $4.22-4.62$, wherein the arithmetic average of the answers reaches 4.42 . In contrast, the standard deviation rates 0.51 , which indicates that the study sample answers are convergent and similar to some extent.

B. The arithmetic mean for the objectivity index ranged 3.75-4.39, whereas the arithmetic average reaches 4.03. In contrast, the standard deviation reaches 0.58 . These results show that the answers of the study sample are harmonized to some extent.

C- The arithmetic averages of the quality of work performance index ranged 3.45-4.11. The arithmetic average reaches 3.92. In contrast, the standard deviation reaches 0.38 . This conclusion shows coherence between the study sample answers to some extent.

D- The arithmetic average of all the relevant statements of internal audit quality variable reaches 4.15. As well, the standard deviation reaches 0.49 . These results show that the answers of the study sample population are harmonized to some extent regarding the expected significant role of the aforementioned indicators.

\section{Hypotheses Testing}

Presented below are the results of the hypotheses:

\subsection{Testing the Main Hypothesis}

The main hypothesis is tested by using the multiple linear regression analysis (Multiple Regression) to realize the impact of the constituents of corporate governance variables on the quality of the internal audit. These constituents are: disclosure, transparency, accountability, responsibility, justice, and independency.

The data of Table 8 explains that there's a significant statistical effect for all of the constituents of the corporate governance on the quality of the internal audit. These constituents are (disclosure and transparency, accountability, responsibility, justice, independency, in addition to laws and regulations); wherein the multiregression $\mathrm{R}$ reaches 0.692 . As well, The $\mathrm{R}$ square variance interpretation rates 0.389 of the variance of the dependent variable. This means that its value is $38.9 \%$ of the changes in the quality of the internal audit. This value results from the changes in the constituents of governance altogether (disclosure and transparency, accountability, responsibility, justice, and independency). The significance of this impact is assured by the value of calculated $\mathrm{F}$ that rates 2.39 , and statistically is significant at $(0.05)$.

Table 8. Results of the OLS of the constituents of corporate governance and the internal audit quality

\begin{tabular}{llcccc}
\hline & Regression Coefficient & Calculated F & (R2) R Square & Correlation Coefficient & Dependent Variable \\
\hline 0.25 & Disclosure and Transparency & & & & \\
0.15 & Accountability & & & & Quality of Internal \\
0.14 & Responsibility & 2.39 & 0.389 & & Audit \\
0.24 & Justice & & & & \\
0.16 & Independency & & & & \\
\hline
\end{tabular}

* The effect is significant at 0.05 . 
The following results of variance analysis shown in Table 9 assure the abovementioned findings. Hence, the value of calculated $\mathrm{F}$ rates 3.01; which is more than the tabular value that reached (2.29), with a significant value at (0.05). As a result, it rejects the null hypothesis and accepts the alternative hypothesis; which states that "there is a significant statistical effect on the quality of the internal audit in the listed public corporations in the Palestine Exchange by applying the constituents of corporate governance represented by: disclosure and transparency, accountability, responsibility, justice, and independency.

Table 9. (ANOVA) effect of the constituents of corporate governance on the quality of the internal audit

\begin{tabular}{|c|c|c|c|c|c|c|c|}
\hline Variable & Variance Source & $\begin{array}{l}\text { Sum of } \\
\text { Squares }\end{array}$ & $\begin{array}{c}\text { Degree of } \\
\text { freedom DF }\end{array}$ & $\begin{array}{c}\text { Calculated } \\
\text { F }\end{array}$ & $\begin{array}{c}\text { Tabular } \\
\text { F }\end{array}$ & Sig. & Result \\
\hline Constituent of & Between Groups & 0.115 & 1 & & & & Rejection of Null \\
\hline Corporate & Among Groups & 5.071 & 29 & 3.01 & 2.29 & 0.0 & Hypothesis \\
\hline Governance & Total Variance & 5.186 & 30 & & & & \\
\hline
\end{tabular}

* The effect is significant at 0.05 .

The effect of applying the constituents of corporate governance on the quality of the internal audit is assured independently. As well, the main hypothesis is divided into six sub-hypotheses. Then, the simple regression analysis (Simple Regression) is used to test each sub-hypothesis individually and as will be discussed later.

\subsection{Testing the Sub-Hypothesis}

Presented below are the results of the sub-hypotheses:

\subsubsection{Testing the First Sub-Hypothesis}

Table 10 comes up with an evident of a statistical significance effect of the disclosure and transparency variable on the quality of the internal audit. Hence, the R correlation coefficient reached 0.67 . In contrast, the R square rates 0.45 of the dependent variable variance, with a significant value at $45 \%$ of the value of the internal audit quality. This results from the changes of the value of disclosure and transparency. The significance of this effect is confirmed by the value of calculated $\mathrm{F}$ which rates 3.315 , with a significant value at 0.05 . This means rejecting the null hypothesis and accepting the alternative hypothesis. Thus, there is a statistical significant effect of applying the disclosure and transparency on the quality of internal audit of the listed public companies in the Palestine Exchange.

Table 10. Simple regression analysis of the "disclosure and transparency" and the quality of internal audit

\begin{tabular}{|c|c|c|c|c|c|}
\hline \multirow[t]{2}{*}{ Dependent variable } & $\begin{array}{l}\text { Correlation } \\
\text { Coefficient }\end{array}$ & $\begin{array}{c}\left(\mathrm{R}^{2}\right) \\
\mathrm{R} \text { square }\end{array}$ & Calculated F & \multicolumn{2}{|c|}{$\begin{array}{c}\text { Degree of freedom } \\
\text { DF }\end{array}$} \\
\hline & & & & Between groups & 1 \\
\hline Internal audit quality & 0.67 & 0.45 & 3.315 & Residuals & 29 \\
\hline
\end{tabular}

$*$ the effect is significant at $(0.05)$.

\subsubsection{Testing the Second Sub-Hypothesis}

Table 11 explains that there is an evident of a significant statistical effect of the accountability on the internal audit quality; wherein the $\mathrm{R}$ correlation coefficient reached 0.58 . The $\mathrm{R}$ square value of the independent variable rates 0.34 . This means that $34 \%$ of the internal audit quality results from the change of the value in the accountability. The significant effect is assured by the value of calculated $F$ which rates 5.36, where the effect is significant at 0.05 . This means rejecting the null hypothesis and accepting the alternative hypothesis assures the significant statistical effect for applying the accountability on the internal audit quality of the listed public companies in the Palestine Exchange. 
Table 11. Analyzing the results of the simple regression of "accountability" on the quality of the internal audit

\begin{tabular}{cccccc}
\hline Dependent variable & $\begin{array}{c}\text { Correlation } \\
\text { Coefficient }\end{array}$ & $\begin{array}{c}\left(\mathrm{R}^{2}\right) \\
\mathrm{R} \text { square }\end{array}$ & Calculated F & \multicolumn{2}{c}{$\begin{array}{c}\text { Degree of freedom } \\
\text { DF }\end{array}$} \\
\hline \multirow{2}{*}{ Internal audit quality } & 0.58 & 0.34 & \multirow{2}{*}{5.36} & $\begin{array}{l}\text { Between groups } \\
\text { Residuals } \\
\text { Total }\end{array}$ & 29 \\
& & & & Tols \\
\end{tabular}

*the effect is significant at $(0.05)$.

\subsubsection{Testing the Third Sub-Hypothesis}

Table 12 explains that there is an evident of a significant statistical effect of the responsibility on the internal audit quality; wherein the $\mathrm{R}$ correlation coefficient reached 0.76 . The $\mathrm{R}$ square value of the dependent variable rates 0.58 . This means that $58 \%$ of the internal audit quality results from the value change in the responsibility. The significant effect is assured by the value of calculated $\mathrm{F}$ which rates 2.81 , where the effect is significant at 0.05. This means rejecting the null hypothesis and accepting the alternative hypothesis assures the significant statistical effect for applying the responsibility on the internal audit quality of the listed public companies in the Palestine Exchange.

Table 12. Results of analyzing the simple regression for the "Responsibility" on the quality of the internal audit

\begin{tabular}{|c|c|c|c|c|c|}
\hline \multirow[t]{2}{*}{ Dependent variable } & \multirow[t]{2}{*}{$\begin{array}{l}\text { Correlation } \\
\text { Coefficient } \\
\end{array}$} & \multirow[t]{2}{*}{$\begin{array}{c}\left(\mathrm{R}^{2}\right) \\
\mathrm{R} \text { square }\end{array}$} & Calculated F & \multicolumn{2}{|c|}{$\begin{array}{c}\text { Degree of freedom } \\
\text { DF } \\
\end{array}$} \\
\hline & & & & Between groups & 1 \\
\hline Internal audit quality & 0.76 & 0.58 & 2.81 & Residuals & 29 \\
\hline
\end{tabular}

*the effect is significant at (0.05).

\subsubsection{Testing the Fourth Sub-Hypothesis}

Table 13 explains that there is an evident of a significant statistical effect of the justice on the internal audit quality; wherein the $\mathrm{R}$ correlation coefficient reached 0.81 . The $\mathrm{R}$ square value of the dependent variable rates 0.66 . This means that $66 \%$ of the internal audit quality results from the value change in the justice. The significant effect is assured by the value of calculated $\mathrm{F}$ which rates 5.56 , where the effect is significant at 0.05 . This means rejecting the null hypothesis and accepting the alternative hypothesis assures the significant statistical effect for applying the justice on the internal audit quality of the listed public companies in the Palestine Exchange.

Table 13. Results of analyzing the simple regression of the "justice" on the quality of internal audit

\begin{tabular}{|c|c|c|c|c|c|}
\hline \multirow[t]{2}{*}{ Dependent variable } & \multirow[t]{2}{*}{$\begin{array}{l}\text { Correlation } \\
\text { Coefficient }\end{array}$} & \multirow[t]{2}{*}{$\begin{array}{c}\left(\mathrm{R}^{2}\right) \\
\mathrm{R} \text { square }\end{array}$} & Calculated F & \multicolumn{2}{|c|}{$\begin{array}{c}\text { Degree of freedom } \\
\text { DF }\end{array}$} \\
\hline & & & & Between groups & 1 \\
\hline \multirow[t]{2}{*}{ Internal audit quality } & 0.81 & 0.66 & 5.56 & Residuals & 29 \\
\hline & & & & Total & 30 \\
\hline
\end{tabular}

*the effect is significant at (0.05).

\subsubsection{Testing the Fifth Sub-Hypothesis}

Table 14 explains that there is an evident of a significant statistical effect of the independency on the internal audit quality; wherein the $\mathrm{R}$ correlation coefficient reached 0.53 . The $\mathrm{R}$ square value of the independent variable rates 0.29 . This means that $29 \%$ of the internal audit quality results from the value change in the independency. The significant effect is assured by the value of calculated $F$ which rates 4.28 , where the effect is significant at (0.05). This means rejecting the null hypothesis and accepting the alternative hypothesis assures the significant statistical effect for applying the independency on the internal audit quality of the listed public companies in the Palestine Exchange. 
Table 14. The results of analyzing the simple regression of the "independency" on the quality of internal audit

\begin{tabular}{cccccc}
\hline Dependent variable & $\begin{array}{c}\text { Correlation } \\
\text { Coefficient }\end{array}$ & $\begin{array}{c}\left(\mathrm{R}^{2}\right) \\
\mathrm{R} \text { square }\end{array}$ & Calculated $\mathrm{F}$ & \multicolumn{2}{c}{$\begin{array}{c}\text { Degree of freedom } \\
\text { DF }\end{array}$} \\
\hline \multirow{2}{*}{ Internal audit quality } & \multirow{2}{*}{0.53} & \multirow{2}{*}{0.29} & \multirow{2}{*}{$\begin{array}{l}\text { Between groups } \\
\text { Residuals } \\
\text { Total }\end{array}$} \\
\hline
\end{tabular}

*the effect is significant at $(0.05)$.

\section{The Results}

The following is a summary of the most important results of the study:

1) The findings of the study state that there is an effect of applying the variables of corporate governance altogether on the quality of the internal audit of the listed public companies in the Palestine Exchange. These rules are (disclosure and transparency, accountability, responsibility, justice, and independency).

2) The results of the study indicate that there is a significant effect of applying the corporate governance variables individually on the quality of the internal audit of the listed public companies in the Palestine Exchange. The effect of these variables appears contrasted respectively as the following: disclosure and transparency, justice and accountability, independency, and responsibility.

3) The corporate governance represents combining the right practices and procedures which operate within the standards and rules that governed by obligatory standards. These standards aim at ensuring that there aren't any contradictions between the strategic goals of the company and the work procedures of the administration in achieving these goals.

4) The internal audit adds value to the company through the functions that enhance its performance within corporate governance. This includes providing information to all levels of the management, evaluating the system of the internal control and the risk management, and obliging the company with the principles of corporate governance.

The findings of the study come up with the following recommendations: (1) The study assures the importance of applying the corporate governance principles because of their clear effect on the internal audit quality. It also recommends working efficiently on the professional development of the auditors and improving their performance through training programs, as well encouraging them to keep up with the latest developments in the field of the auditing and other working fields. (2) It strongly recommends working on enhancing and activating the role of the board of directors and the audit committee as well as granting them the independency. Hence, they will be able to carry out the tasks assigned to them. Consequently, they will avoid the effects that the company may be exposed to as a result of the internal weakness of the practical aspects of the principles of corporate governance; in addition to the negative impacts of this issue on the quality of internal audit.

\section{References}

AICPA. (1991). The Auditors' Consideration of the Internal Audit Function in an Audit of Financial Statements. Statement on Auditing Standards no. 65, New York, NY: AICPA, 1991.

Al A'neiand Al Ghazaw. (2012). The Internal Audit within the Corporate Governance and its Role in Enhansing the Company Value. The University of Baghdad, Baghdad, Iraq.

Al Issawi, I. (2003). The Development in a Changing World: A Study on the Concept of The Development and it Indicators. Cairo: Dar Al Shorouk for Publishing.

Al Qadi, H. (2008). The Internal Audit (1st ed). Damascus, Damascus University Publications.

Al Sa'dani, H. M. B. (2005). The Internal Audit within the Corporate Governance and From the Perspective of the Nature of the Internal Audit Services. The Arab Organization for Administrative Development, Cairo, Egypt.

Al-abali M., Abdalmanam, O., \& Ziadat, K. (2011). Internal Audit and its Role in Corporate Governance. Middle Eastern Finance and Economics, 11, 161-176.

Alamgir, M. (2007). Corporate Governance: A Risk Perspective. Paper Presented to: Corporate Governance and Reform: Paving the Way to Financial Stability And Development, A Conference Organized by the Egyptian Banking Institute, Cairo, May, 2007. 
Alqubj, N. (2002). The Internal Control between the Theory and Practice in Palestine Corporate. Annajah National University Library: Nablus - Palestine.

Archambeault, D. S. (2002). The Relation between Corporate Governance Strength and Fraudulent Financial Reporting: Evidence from SEC Enforcement Cases. USA: Prentice-Hall International, Inc.

Carroll, A. B. (2003). The Pyramid of Corporate Social Responsibility Business Ethics and Social Responsibility. Retrieved from http://www.socpa.org.sa/rule/index.htm

Dirdis, K. W. (2010). The Effect of Providing the Internal Audit Services from External Parties on the Quality of the Internal Auditing of the Listed Companies in the Oman Burce: An Empirical Study. Unpublished Master Thesis, School of Business, Department of Accounting, Jadara University, Irbid: Jordan.

Fateh, D., \& Aishi, I. (2008). Corporate Governance as a Tool to Ensure the Veracity of Financial Information and Accounting Systems and its Impact on the Functioning of Markets Performance. Research Presented to the Third Scientific Conference to the Faculty of Economics and Administrative Sciences, Applied Science Private University, Amman, Jordan.

Gum'a, A. H. (2003). The Institutional Governance and the Dimensions of the Development in the Internal Audit Function, the Jordanian Association of Certified Public Accountants. The Fifth Scientific Professional Conference, Titled: the Institutional Governance and the Corporate Continuity, Amman, Jordan 24-25 of September, 2003.

Ibrahim, M. A. (2005). Proposed Model for the Activation of the Rules of Corporate Governance - In Within the International Standards of Internal Audit. the Arab Organization for Administrative Development, Faculty of Commerce, Menoufia University, cairo- Egypt.

Isa, S. K. M. (2008). The Determinants of The Function ofthe Internal Audit Quality in Improving the Quality of Corporate Governance: With Anempirical Study. Journal of the Faculty of Commerce for Scientific Research, 45, 1-57.

Karagiorgos, T., Drogalas, G., Gotzamanis, E., \& Tampakoudis, L. (2010). Internal Auditing as an Effective Tool for Corporate Governance. Journal of Business Management, 2, 15-23.

Keirazan, F. H. (2013). The Influence of the Internal Audit in Applyingthe Corporate Governance on the Syrian Public and Private Banks. The University of Damascus, Damascus, Syria.

Khoury, N. S. (2003). The Accounting Profession between the Financial Distress and the Institutional Control of the Companies. Al-Bayan Newspaper, may 25, the United Arab Emirates.

Mangena, M., \& Pike, R. (2005). The Effect of Audit Committee Shareholding, Financial Expertise and Size on Interim Financial Disclosures. Accounting and Business Research, 35(4), 327-549. http://dx.doi.org/10.1080/00014788.2005.9729998

Mattar, M. (2003). The Role of the Disclosure of Accounting Data to Promote and Activate the Institutional Arbitration. The Jordanian Association of Certified Public Accountants, the Fifth Professional Scientific Conference, Amman, Jordan 24 - 25 of September, 2003.

Mattar, M. N., \& Abdel, N. (2007). The Effect of the Jordanian Public Companies Commitment to the Principles of Corporate Governance, A Comparative Analysis between the Banking and Industrial Sectors. Jordan Journal of Business Management, 3(1), 46-71.

Messier, Jr. W. F. (2000). Auditing \& Assurance Services: A Systematic Approach (2nd ed.). New York: Mcgraw-Hill Companies, Inc.

OECD. (1999). Principles of Corporate Governance, Organization for Economic Co-Operation and Development Publications $\quad$ Service, $1999 . \quad$ Retrieved from http://www.oecd.org/corporate/ca/corporategovernanceprinciples/31557724.pdf

Palestine Exchange PEX. (2010). Public Relations Department, Annual Bulletin, 2010.

Rezaee, Z. K., \& Mimmier, G. (2003). Improving Corporate Governance: The Role of Audit Committee $\begin{array}{llll}\text { Disclosures. } & \text { Managerial }\end{array}$ http://dx.doi.org/10.1108/02686900310482669

Tabara, N., \& Ungureanu, M. (2012). Internal Audit and Its Role in Improving Corporate Governance Systems. Annales Universitatis Apulensis Series Oeconomica, 14(1), 139-145. Retrieved from http://www.oeconomica.uab.ro/upload/lucrari/1420121/12.pdf 
Tamimi, H. (1998). The Entrance to the Audit: Theoretical and Practical Study. Oman, Khalon Center for Publications.

Williamson, Q. E. (1999). The Mechanism of Governance. Oxford: Oxford University Press.

Zingales, L. (1997). Corporate Governance. NEBR Working Paper, 1997. Retrieved from http://www.theiia.org

Zuelf, \& Abdali. (2010). The Effect of Applyingthe Corporate Governance on the Quality of the Internal Audit. Zaytuna University of Jordan, Amman, Jordan.

Zuelv, In'am, \& Al Jawhar, K. (2007). The Role of the Commitment With Theelements of the Internal Control in Strengthening the Foundations of Institutional Control. The Magazine of the Research and Humanitarian Studies, 232-258.

\section{Copyrights}

Copyright for this article is retained by the author(s), with first publication rights granted to the journal.

This is an open-access article distributed under the terms and conditions of the Creative Commons Attribution license (http://creativecommons.org/licenses/by/3.0/). 